\title{
MODE AND CHANGE OF MODE IN THE 13th-CENTURY MOTET
}

\author{
Marie Louise MARTÍNEZ-GÖLLNER
}

\begin{abstract}
The many different versions in which motets were notated in various manuscripts from the 13th century testify to the great flexibility of this genre. The present paper pursues those few clues in practical and theoretical sources which indicate that the rhythmic mode itself was often subject to change within a particular group of motets. Evidence of this practice is found in the early group of the manuscripts and then, again, in the later, more liturgically oriented sources, including Las Huelgas. In the former, first and second modes could be interchanged to correspond to Latin or French texts, respectively, and in later times the notated combination of third and fifth modes, now considered out of date, could simply be performed as sixth and second modes. In both cases the change of mode appears to represent a quasi-improvisatory practice which could be performed without altering the written version, i.e. it was probably much more common than the sources themselves indicate.
\end{abstract}

\section{Resumen}

La mayoría de las diferentes versiones en las que eran anotados los motetes en varios manuscritos desde el siglo xiII dan fe de la gran flexibilidad de este género. El presente artículo se centra en las pocas claves existentes en las fuentes prácticas y teóricas que indican que el modo rítmico en sí mismo estaba, a menudo, sujeto a cambios dentro de un grupo concreto de motetes. La evidencia de esta práctica se halla en un grupo temprano de manuscritos y después, de nuevo, en los posteriores, que son fuentes más orientadas hacia la liturgia, incluyendo Las Huelgas. Al principio, el primero y segundo modos podían ser intercambiados para corresponderse con textos en latín o en francés, respectivamente, y en posteriores ocasiones la combinación anotada de tercer y quinto modos, ahora considerada anticuada, podía ser interpretada simplemente como sexto y segundo modos. En ambos casos el cambio de modo aparece para representar una práctica casi improvisatoria la cual podía ser interpretada sin alterar la versión escrita, o sea, era una práctica posiblemente más común que lo que indican las propias fuentes.

One of the most striking aspects of the medieval motet is the immense flexibility of which it was capable. Texts and voices seem to have been added or subtracted at will, other pieces quoted, refrains interpolated, and so on. As a result, it is not possible to speak of a 'work' in the usual sense of a specific composition; rather we find groups of pieces which are centered around a common musical core of tenor and duplum with a repeating rhythmic pattern. Where different texts are involved in the upper voices, it is often very difficult, if not impossible, to determine which of them was the primary or original one, and this uncertainty extends as well to the relationship between motet and untexted clausula in the Notre Dame manuscripts. ${ }^{1}$

1. For a challenge to the traditional view of the priority of the clausula see particularly W. FroBENIUS, "Zum genetischen Verhältnis zwischen Notre-Dame Klauseln und ihren Motetten," AfMw 44 (1987), 1-39. 
The present article is devoted to yet a further possible change within these motet families, namely a change in the rhythmic mode, often affecting the tenor itself as well as the upper voices. A comparison among the various sources shows that these changes can be found in two main periods in the history of the motet, namely among the clausulae and motets of the Notre Dame manuscripts, that is, at a relatively early stage, and then secondly, in the latest, often peripheral, manuscripts containing motets and motet voices. The central motet collections in quasi-Franconian notation, in contrast, remain generally constant in this respect. ${ }^{2}$ Since the early, and often also the late, group of manuscripts did not make use of clear rhythmic notation for the motets, it is often difficult to find clear evidence for the changes. As we will show, however, these may well have been simply a matter of performance, necessitating little or no alteration of the written version.

The changes themselves occur primarily between the first and second rhythmic modes on the one hand and the third and sixth on the other. In the first case they apparently reflect the later popularity of the second, or iambic, mode, which could be aptly combined with French texts but frequently resulted in a clash with Latin, i.e. trochaic, texts. Whereas the collectors represented in the central sources appear to have found no difficulty with this combination and may well have even relished the dichotomy which it produced between textual and musical rhythm, there are indications that other, often more liturgically oriented, sources sought to avoid it. And this could be achieved either by changing the second mode to the first or, less frequently, by evening out the syllables into a series of equal Longs.

As the first example we will consider the group of motets numbered 371 to 375 by Ludwig and Gennrich. ${ }^{3}$ Based on the tenor 'Mulierum' from the 'Alleluia. Inter natos' for the feast of St. John the Baptist (M 29), this family includes a variety of motet texts in both French and Latin for two and three voices but no known clausula which could have provided an early rhythmic notation. The motets, however, are found with various texts in several of the early Notre Dame manuscripts: in F (f. 392v) as a three-voice motet with the single Latin text, 'Prodit lucis radius', sung simultaneously in both of the upper voices; in W2 in two different two-voice versions, one with the French text, 'En grant effroi' (f. 217v), and one with the Latin, 'Prima cedit femina' (f. 184r). With the French text it is also transmitted in the chansonniers, $R$ (f. 206v) and N (f. 186r). In all of these early sources the rhythmic mode is not indicated in the notation. Since the tenor consists of groups of three-note ligatures which could be interpreted variously as first, second or fifth mode, the only clue - and a vague one at best - is the frequency of two- and three-note groupings on the even-numbered syllables of the text, a feature often associated with the second mode.

2. The early group includes the Notre Dame Mss.: Florence, Plut. 29,1 (F); Wolfenbuittel 628 and 1099 (W1 and W2); Madrid, Bibl. Nac. 20486 (Ma); and the chansonniers, Paris, Bibl. Nat. frc. 844 (R) and 12615 (N). The central collections are represented principally by Montpellier $\mathrm{H} 196$ (Mo) and Bamberg Lit.115 (Ba), and the later group by Las Huelgas (Hu) and London, BL, Add. 27630 (LoD). For the complete library sigla and descriptions of these manuscripts see the works by Ludwig and Gennrich quoted below (fn.3) and Series B IV of Répertoire Internationale des Sources Musicales (RISM).

3. F. LudwIG, Repertorium organorum, Halle 1910; F. GENNRICH, Bibliographie der ältesten französischen und lateinischen Motetten (= Summa musicae medii aevi, ii), Darmstadt 1957. 
Montpellier and Bamberg take over the music of the earlier sources, including the triplum of F, and adapt the two different versions of W2 to form 3-voice French and Latin motets respectively. Whereas Mo adds a new French text as the triplum of the French version (f. 123r), Ba transfers the Latin text from the duplum of W2 to the triplum and adds a new text to the music of the duplum (f. 37r) ${ }^{4}$ The very fact that a single text could be transferred from one upper voice to the other points to a unique feature of this particular motet, namely that both upper voices have exactly the same phrasing, and hence all of the many different texts the same number of lines and syllables:

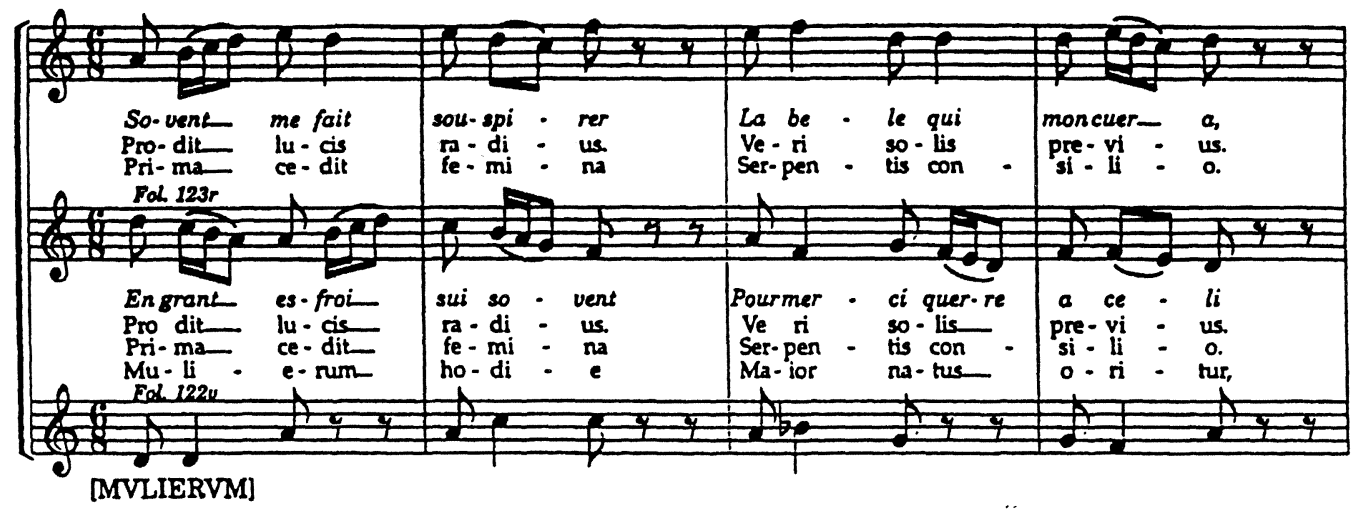

As the example shows, four different texts were set to the same music of the duplum and three to that of the triplum. The primary text, and the only one to fit the second mode of the main motet collections is here clearly the French duplum of W2 and the chansonniers, 'En grant effroi'. The very multiplicity of the Latin texts, in contrast, would seem to indicate that they were contrafacts. This makes the Bamberg version all the more noteworthy. Even though it must probably be considered the latest of all of the Latin texts, it is also the one most closely related to the tenor, starting and ending with the word 'mulierum'.

The music, in contrast to the many different texts, remains the same in all versions, an unusual situation, particularly for Mo, which usually adds new triplum lines, often of a more ornate nature, to the two-voice core of tenor and duplum.

Since both Mo and $\mathrm{Ba}$ notate their respective versions clearly in the second mode, the question of a change might well appear idle were it not for the third group of later manuscripts. In Las

4. For transcriptions of the versions from these two sources see Y. RoKsETH, Polyphonies du XIIle Siècle, Paris 1936, Vol. 2, 175 (Mo) and P. Aubry, Cent Motets du XIIle Siècle, Paris 1908, Vol. 2, 129 (Ba). For a more recent edition of the motets in Ba see G. Anderson, Compositions of the Bamberg Manuscript (CMM 75), AIM 1977. 
Huelgas, namely, the tenor and Latin duplum of Ba have been notated very clearly in the first rhythmic mode, accompanied by the somewhat testy comment by the scribe, "Tenura de mulierum et cantasse por natura" (fol. 110r). ${ }^{5}$
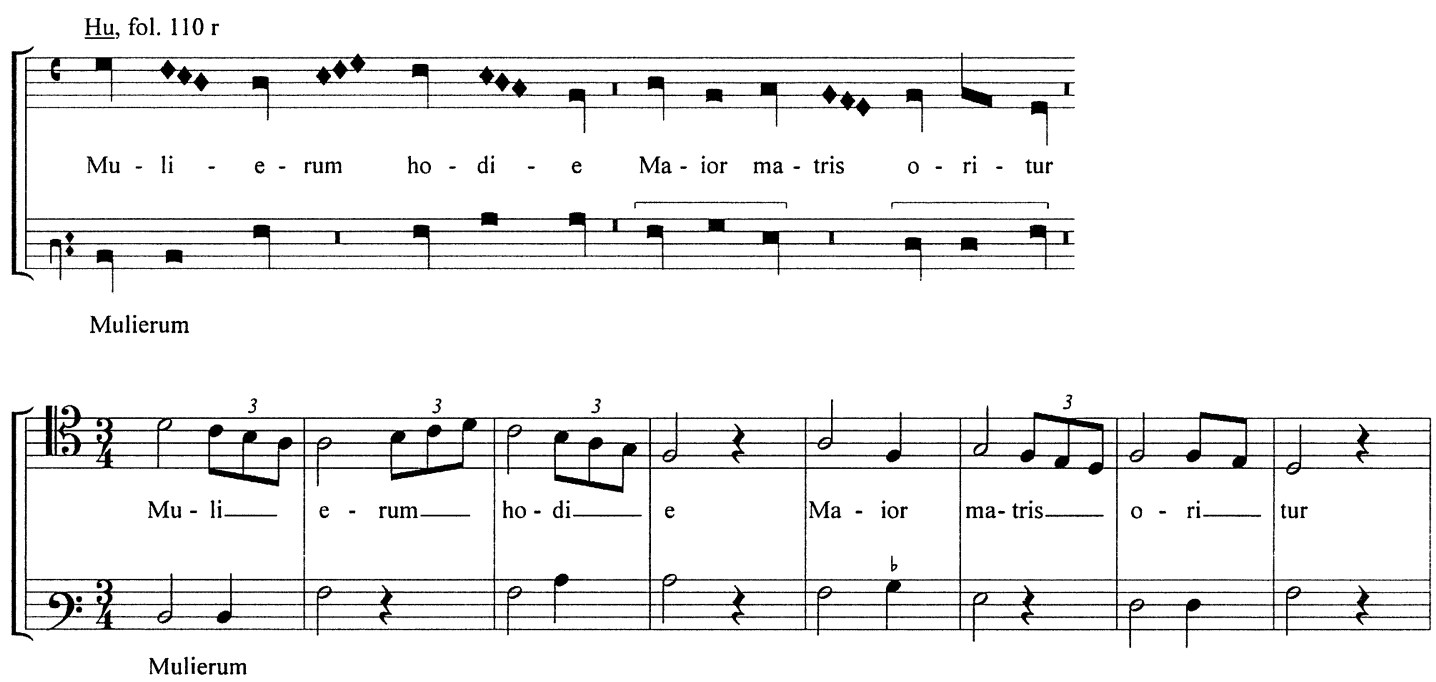

That the scribes, and consequently also the performers, of the Middle Ages were indeed aware of the problem of rhythm and its coordination in text and music is further supported by two variant versions of this motet, both of which quote the word, 'Mulierum' and its melody as the beginning of the upper voice. The first, likewise found in Hu ('Mulier misterio', f. 90r), keeps the tenor of the main version, again notating both voices in the first mode. The second, in the manuscript LoD ('Mulierum hodie/Inter natos mulierum', f. 59v), changes both voices to the third rhythmic mode, declaiming the syllables of the upper voice, however, in even long values. ${ }^{6}$ This syllabic equality, then, constitutes a further method of resolving the clash between text and musical rhythm.

The main question thus concerns the earlier Latin versions of the Notre Dame manuscripts. Could they, too, have been performed in the first rhythmic mode? As we have seen above, the structure of the music itself allows either first or second mode with virtually no changes, and the rhythmically neutral notation of the early manuscripts could have been interpreted either way with equal ease.

Although particularly wide-ranging in its many notated versions, the above example is by no means isolated within the motet repertoire of the 13th century. In cases where clausulae have been

5. The entire motet is transcribed in H. ANGLÈs, El Còdex Musical de Las Huelgas, Barcelona 1931, Vol. 3, 213f. For a more recent edition, which differs in many details, see also G. ANDERSON, The Las Huelgas Manuscript, (CMM 79), AIM 1977.

6. See ANGLÈs, Vol. 3, 143f (Hu). The second motet, in the so-called Engelberg style with texted tenor, is transcribed in W. Dömling, Die Handschrift London, British Museum Add. 27630 (LoD) (= Das Erbe Deutscher Musik, 53), Kassel 1972, 50. 
preserved, they, too, may differ from the motet with regard to the rhythmic mode, or are themselves inconsistent in their notation.

In the first group are two related two-voice motets in the second motet fascicle of $\mathrm{F}$, both on the tenor segment ' $\mathrm{Ta}$ ' (captivitatem) from the 'Alleluia. Ascendens Christus in altum' (M 23, Gennrich 307 and 308). Found only in the earliest group of manuscripts, both have single Latin texts: 'Scandit solium' and 'Hostem superat' respectively. Since the tenors follow the upper voices basically note-for-note in patterns of five notes each, their notation in ligatures is indicative of the rhythm in both voices, in the motets as well as in the clausulae: $3+2$ (first mode) or $2+3$ (second mode). As the more widely transmitted of the two, 'Scandit solium' is found in F as a three-voice motet (f. $386 \mathrm{r}$ ) and as a two-voice clausula (f. 160v), both notated in the second mode. In the two-voice motet of W2, however, the tenor is just as clearly in the first mode, indicating the same for the upper voice. The other motet, 'Hostem superat', preserved again in F as both clausula (f. 160v) and motet (f. $401 \mathrm{v}$ ) in the second mode, is found in W1 (f. 57v) as a clausula in the first mode. ${ }^{7}$ For these two motets, then, the manuscript $F$ seems to stand alone in its preference for the second mode, whereas both W1 and W2 have notated them in the first mode.

The second possibility, i.e. inconsistency in the notation of a single source, can be illustrated by the group of motets, numbers 636-640, on the tenor 'Tamquam' from the Responsory, 'Descendit de celis' $(\mathrm{O} 2)$. Here the tenor alternates between three single Longs and five shorter notes which must be combined into ligatures, again, that is, $3+2$ or $2+3$. The basic two-voice core, found in $F$ (f. 10v) as a clausula and in W2 (f. 154v) as a motet with the Latin text, 'Tamquam suscipit' in the duplum, has been expanded in all of the other versions to three and even four voices. Although the manuscripts of the second group again notate their versions, with both French and Latin texts, in the second mode ${ }^{8}$, the earlier sources are generally inconsistent in their use of ligatures, including both possibilities in their notation. Both of the two-voice versions, in particular, appear to favor the first mode arrangement of ligatures in their tenors, although neither is consistent. ${ }^{9}$ Whereas the French text 'Debonairement' of Mo fits the rhythm of the second mode very well, the Latin, 'Tamquam suscipit' of W2 contains many awkward emphases on short syllables, e.g. the second syllables of 'domini' and 'graciam' or the semibreves on the first word 'Tamquam'. This obviously did not present a problem for the three- and four-voice versions of this particular motet as transmitted in the central motet collections. In the two-voice version, however, the single text would have been considerably more prominent, and the first mode could easily have been employed without changing the music:

7. For transcriptions of both the clausulae and the motets in their different versions see H. TiSCHLER, The Earliest Motet: (to circa 1270), New Haven and London 1982, Vol. 1, 139ff ('Scandit solium') and 362ff ('Hostem superat'). G. ANDERSON, The Latin Compositions in Fascicules VII and VIII of the Notre Dame Manuscript Wolfenbüttel Helmstadt 1099 (1206) (Musicological Studies, XXIV), Brooklyn 1976, "corrects" the version of 'Scandit solium' in this source to the second mode (see Vol. 1,266 and Vol. 2, 174).

8. Mo transmits a four-voice French version (f. 46v) with 'Deboinerement' as the triplum (see RoKSETH, Vol. 2, 67ff); $\mathrm{Ba}$, however, adds a new triplum with the related Latin text, 'Tamquam agnus', to the earlier duplum (see Aubry, Vol. 2, 193f).

9. This apparent confusion in the notation of the ligatures as well as conspicuous differences in both pitch and phrasing between the motet and its clausula have led W. Frobenius to conclude that the latter may well have represented an attempt, albeit not always successful, to convert the motet to ligature notation without text. See the above-cited article, p. 19. 
Mo, fol. $46 \mathrm{v} ; \underline{\mathrm{Ba}}$, fol. $55 \mathrm{v}$
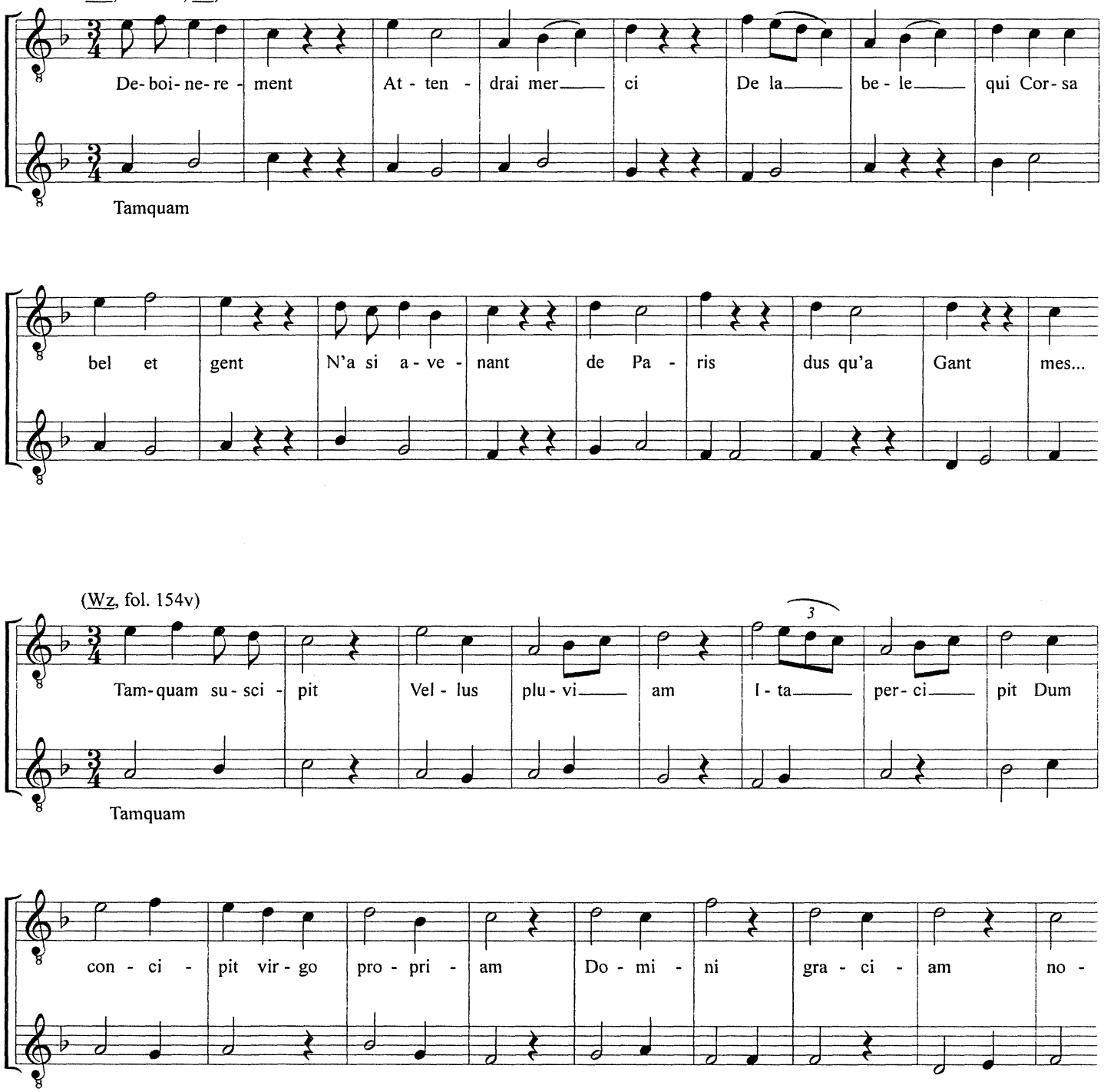

From these examples - and there are many more - we gain the impression that the second rhythmic mode assumed a place of special prominence in the mature phase of the motet, particularly in connection with French texts and with the increasing popularity of three-voice versions. There also appears to be a relationship to certain manuscripts, notably to the large collections from the later 13th century in Franconian notation. The earlier sources, in contrast, and also the more liturgically oriented manuscripts of the later period, were frequently more concerned with providing a rhythm suitable to their sacred Latin texts. 
There were several ways of accomplishing this without altering the actual substance of the voices. Many motets, for instance, even those with French texts, weaken the abrupt character of declamation in the second mode by consistently adding notes to the concluding longs of the pattern in the upper voice, thus obscuring the difference between Breve and Long in the music (See above, Ex. 1, 'En grant effroi').

Yet another method can be observed in the different versions of the motet, 'In Bethleem', based on the tenor segment with the same text from the Gradual, 'Laus tua' for the feast of the Innocents (M 8; Gennrich 98-99). Here the text of the duplum is clearly designed as a trope on the verse of the Gradual: "Herodes iratus occidit multos pueros in Bethleem Jude civitate David." Transmitted as a clausula in all three of the main Notre Dame manuscripts, in W2 (f. 68r) and F (f. 105r) as part of the Gradual itself, it is also found in these two sources as a motet, for two and three voices respectively (W2, f. 163r; F, f. 382r). The ligatures at the beginning and end of all four of these versions indicate a performance in the second mode. The clausula in W1 (f. 50v), however, as well as the motet in Madrid (f. 125), are just as clearly notated in the first mode: ${ }^{10}$

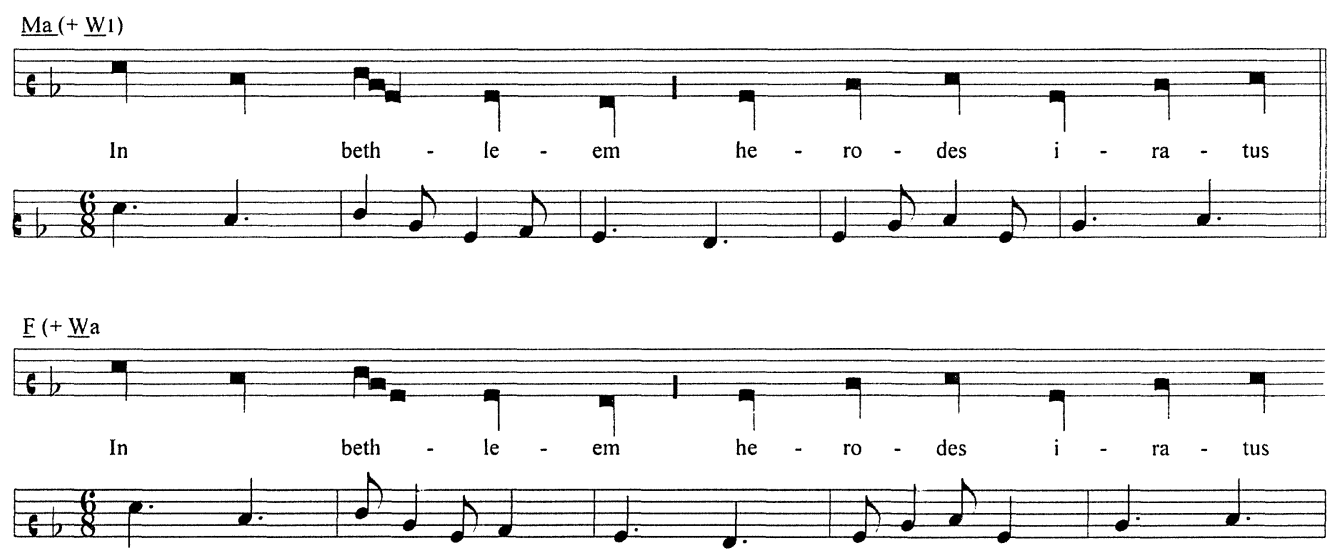

The motet subsequently achieved a rare stability in its three-voice version with the triplum, 'Chorus innocentium', also closely related to the text of the Gradual. In this case, however, the triplum, in the third rhythmic mode, was not merely added to the two-voice core but actually changed the rhythm of both of those voices to even Longs, or the fifth mode, in which form it is transmitted in $\mathrm{Ba}(\mathrm{f} .24 \mathrm{v})$ and several other related sources: ${ }^{11}$

10. See the transcription of the different versions in H. TiSCHLER, op. cit., Vol. 1, 80ff (with the clausula of W1 in the first mode, but the motet of Ma in the second!).

11. See Aubry, Vol. 2, 89. Curiously, the motet is not included in any form in Mo. 
Ba - Mode 3 and 5

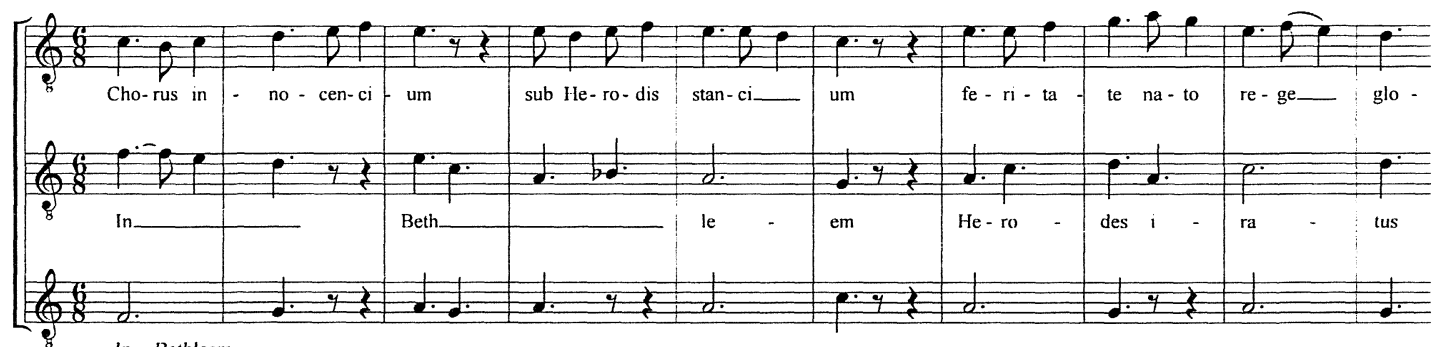

In Bethleem

For this type of rhythmic alteration we have further evidence. It is described in some detail by the theorist known as Anonymous St. Emmeram in his mensural treatise dated $1279 .{ }^{12}$ In the second chapter of this work the author tells us how motets can be converted from what he calls the long modes, i.e. third, fourth or fifth rhythmic modes, to the short ones, i.e. second or sixth, and vice versa. According to him this can be done in performance without difficulty and without changing the notation, simply by following his method:

"Nam si sit tercie sive quarte et hoc regulariter iuxta artem, in sextam speciem simpliciter convertetur nihil aliud addito nihilque aliud transmutato... Si quis autem memorie commendaverit hanc doctrinam, omnes motellos ex tercia specie sive quarta similiter et ex quinta, compositos et confectos de longo modo in brevem aut etiam e converso absque labore convertere poterit pro mutua voluntate..."

And to illustrate his point he gives two examples, one of which is the three-voice 'In Bethleem', changing the combination of third and fifth modes as found in the mensural sources to the sixth and second modes, a form, that is, which, although not found in any of the sources, is actually closer to the earlier versions of the two-voice motet:

12. Ed. H. SowA, Ein anonymer glossierter Mensuraltraktat 1279 (= Königsberger Studien zur Musikwissenschaft, 9), Kassel 1930. For a thorough discussion of the treatise and its origins see the Foreword to the more recent edition with English translation by J. YudKIN, De musica mensurata, Bloomingdale, Ind. 1990. Sowa, in particular, pointed to the importance of the comments on change of mode (see his introduction, XIXff). 


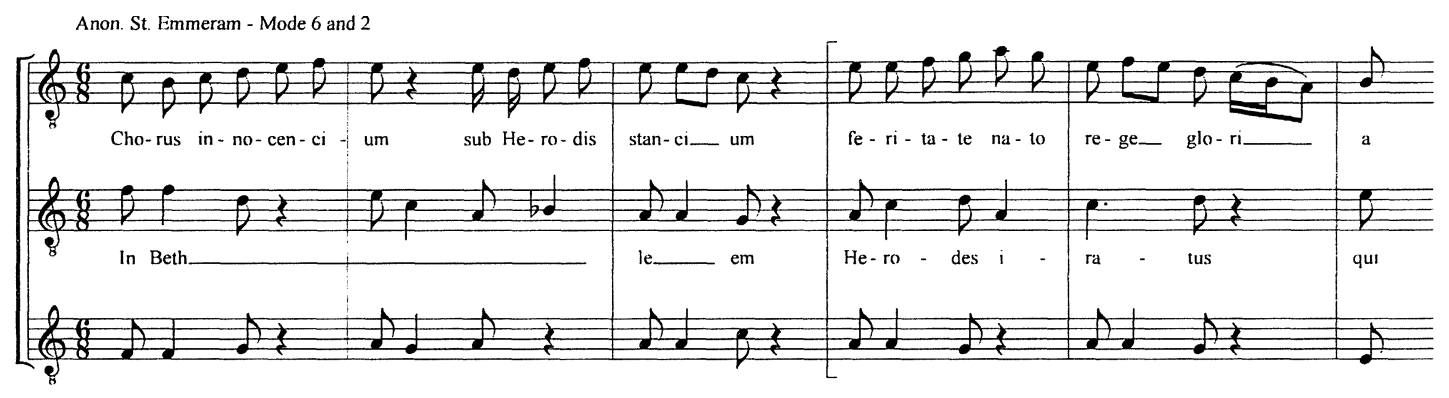

The second example provided in the treatise to illustrate this practice is the motet, ' $\mathrm{O}$ natio nefandi/ Conditio nature/Mane prima' (Gennrich 598-599), preserved in a variety of sources including both $\mathrm{Ba}$ (f. $49 \mathrm{v}$ ) and Mo (f. $87 \mathrm{v}$ ), with all three voices notated in the third mode. ${ }^{13}$ According to the anonymous author, these can all be changed to the sixth mode, a version not found in any of the sources:

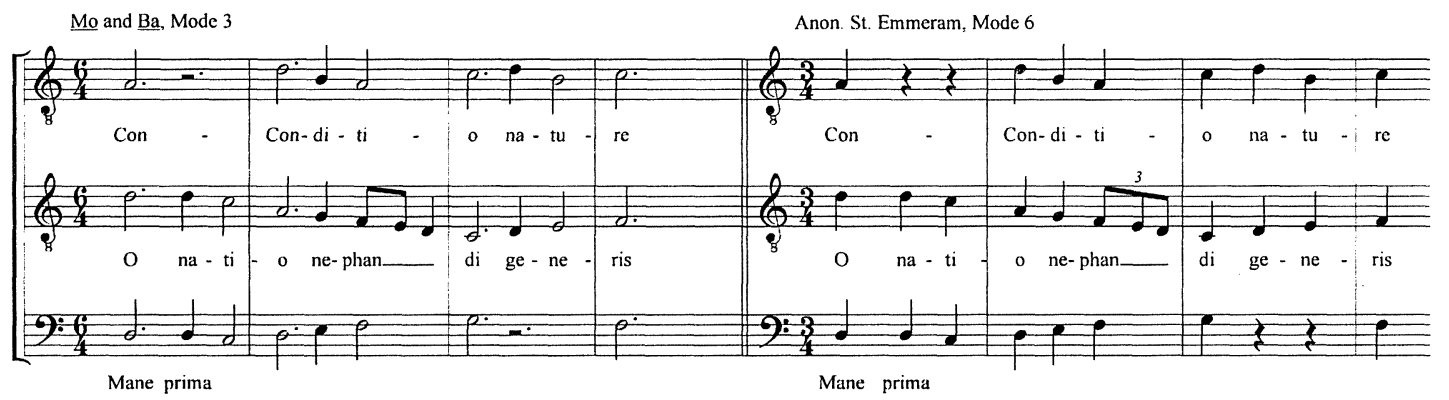

Here, then, is confirmation of a practice which could be carried out "supra librum" as it were, in converting the so-called longa to the brevis modes or vice versa. A trained singer should, according to this writer, be able to read the third or fourth rhythmic mode as the sixth and the fifth mode as the second, or the other way around. And, on the basis of Franconian notation this would, in fact, be extremely simple. Since tenor voices notated as ligature groups of three notes could be read fascicle).

13. See Aubry, Vol. 2, 172 (Ba) and Rokseth, Vol. 2, 120 (Mo, where the motet is placed at the beginning of the 4th 
variously as first, second or fifth mode, their notation would remain the same; and an upper voice in the third mode need only be read as groups of three breves instead of a long plus two breves in order to convert it from the third to the sixth mode. Generally no further changes would be necessary, but the performer should be able to make minor adjustments as demanded to accommodate the text or preserve the proper consonances.

In the late group of more liturgically oriented manuscripts with Latin-texted motets, it is generally the opposite procedure which is followed, i.e. the change away from the second mode to the third and fifth. As in our first example above, it is mainly the manuscripts Las Huelgas and LoD which are involved, and here the tendency is to notate the third mode in binary rather than ternary values, i.e. to give the two breves equal value. In such instances the declamation frequently follows the fifth mode, presenting the syllables in equal Longs. A good example is the well-known motet, 'Gaude chorus omnium/Angelus', from the 'Alleluya. Angelus domini descendit' (M 20, Gennrich 263-268). Although there is no clausula, the two-voice motet is found in several of the earlier manuscripts with the French text, 'Aucuns m'ont par lour envie' (W2, f. 252v) a text, that is, which can easily be sung in the second mode, as indicated in the three-voice version in Mo (f. $174 \mathrm{v}$, with the triplum, 'J'ai si bien', also in Mode 2). In a second version from this manuscript (f. 71v), however, found also in $\mathrm{Ba}$ (f. 19v), the duplum, now with the Latin text, 'Gaude chorus', is still notated in the second mode and accompanied by the triplum, 'Povre secours' in the sixth mode. ${ }^{14}$ In this case the Latin text, again a kind of trope on the verse of the Alleluya, is conspicuously ill-suited to the rhythm of the second mode. Not only do emphases occur consistently on the wrong syllables but the words themselves are broken up in the process:

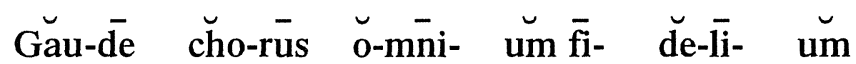

Here again the clash between music and text is somewhat alleviated by the consistent addition of extra notes to fill out the long values and, in the three-voice version, by the running notes of the triplum. It is nonetheless noteworthy that this particular motet should have been singled out by several of the theorists as an illustration of the second mode and its use in both voices. ${ }^{15}$

Of the three manuscripts which transmit the Latin version alone as a two-voice motet, two, Madrid (f. 134r) and ArsB (f. 117v), give no indication of rhythm and the third, Las Huelgas (f. 87r), clearly notates both voices in the third mode, setting the syllables of the text in the duplum in even

14. See Rokseth, Vol. 2, 244 and 95 (Mo) and Aubry, Vol. 2, 71 (Ba). Since the music -as opposed to the text declamation - of the duplum, 'Gaude chorus', is consistently in Breves, or the sixth mode, the two voices thus proceed mainly noteagainst-note.

15. See, for example, the Discantus positio vulgaris, (ed. in Coussemaker, Scriptores, Vol. I, 96): "Item secundi modi tenor aliquando cum moteto convenit in notis, sicut hic in parte", or, referring to Franco of Cologne, Anon. 2 (CS I, 307): "Secundus [modus] constat ex brevi et longa, ut hic." The same treatise quotes the beginning of 'In bethleem' as an example for Franco's first mode, proceeding "ex omnibus longis". 
long syllables, or the fifth mode. The scribe has, that is, converted the motet from the brevis mode to the long mode as described by Anon. St. Emmeram: ${ }^{16}$

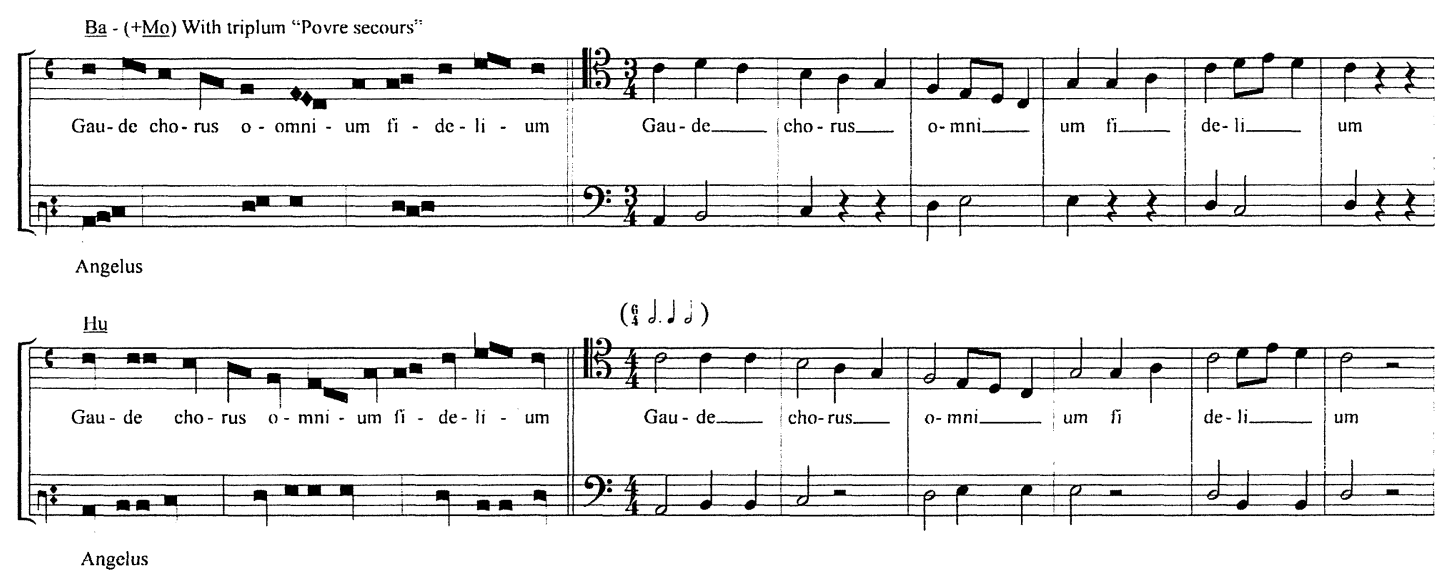

A final example from Las Huelgas may serve to illustrate how easily the third and the sixth mode could be interchanged, particularly when combined with the type of Latin text which was typical for the former: a series of three-syllable words preceded by a four-syllable word or unit (e.g. one plus three). ${ }^{17}$ Although the two duplum texts are here different, the music is the same, notated at different points of the manuscript, once in the third and once in the sixth mode, the former accompanied by a triplum likewise in the third mode: ${ }^{18}$

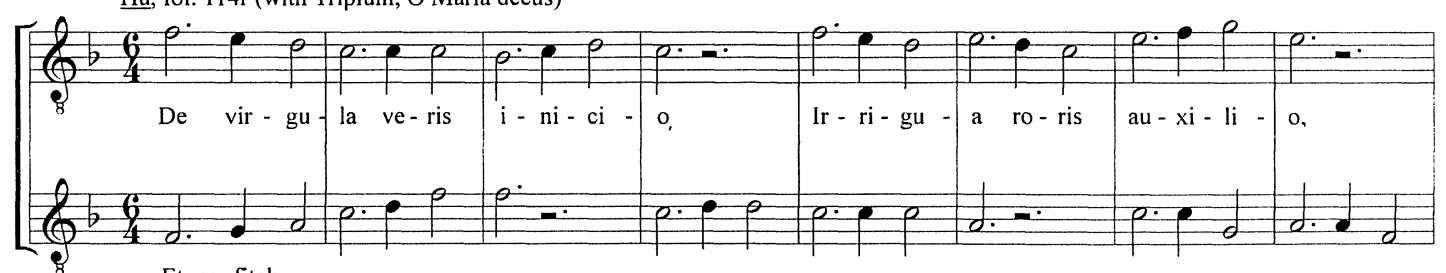

Et confitebor

16. Whereas ANGLÈs transcribes the motet in duple time, i.e. with equal Breves (Vol. 3, 130), ANDERSON preserves the traditional triple division, which doubles the value of the second Breve (Vol. 2,8).

17. For a more thorough discussion of these characteristics see M.L. Göllner, "The Third Rhythmic Mode in the thirteenth and fourteenth centuries", Revista de Musicología, 16, 4 (1993), pp. 2395-2409.

18. 'De virgula/O Maria/Et confitebor' (Hu, f. 114) and 'Ecclesie princeps/Et confitebor' (Hu, f. 128r/v). The tenor is taken from the 'Alleluya. Adorabo ad templum' (M 12; Gennrich 112 and 112b). See the transcriptions in ANGLÈs, Vol. 3, 228 and 297. The two-voice 'De virgula' is also found as a motet in W2 (f. 157r) and as a clausula in F (f. 154v). See TISCHLER, Vol. 1, 802 (both motets) and ANDERSON, The Latin Compositions [of W2], Vol. 2, 79 ('De virgula'). 


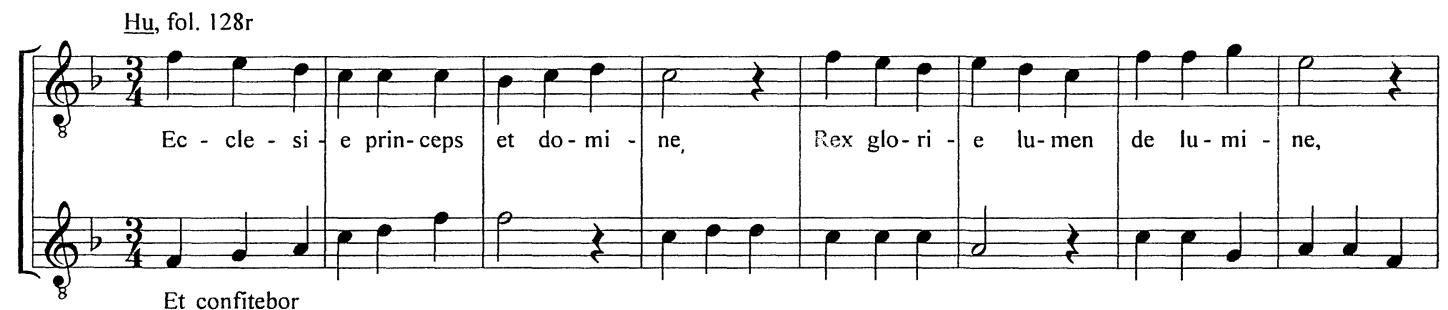

From all of the above evidence we can conclude that motets were, in fact, sung in different rhythmic modes within the boundaries discussed, and that this practice was carried out on a quasiimprovisatory basis, i.e. to a much greater extent than that actually found in the written sources. If it could involve the changes described by Anonymous St. Emmeram, it was also very likely applied to the interchange of the first and second rhythmic modes within the earlier, non-mensural sources. In conclusion I would like to suggest that the criteria for these changes were primarily textual and liturgical, and not necessarily tied to the chronology of the various manuscripts. Both the second and sixth modes, however, appear to have enjoyed a definite modern appeal in the later part of the 13th century as opposed to the more conservative first and third modes. Although they were both best suited to French texts, they were thus frequently imposed on Latin texts as well, particularly in the central motet collections, such as Bamberg and Montpellier, and particularly in combination with added voices as three- and four-voice motets. The more liturgically oriented manuscripts of both the early and late groups, in contrast, such as $\mathrm{W} 1$ and $\mathrm{Ma}$, or $\mathrm{Hu}$ and LoD, which transmitted the motets mainly in their simpler, two-voice form, frequently sought to avoid both the French texts and the rhythmic modes associated with them by writing Latin contrafacta and changing the modes in the ways we have observed. 